\title{
Sedimentology of reefal buildups of the Xiannüdong Formation (Cambrian Series 2), SW China
}

\author{
Hao Tang ${ }^{1,2,3^{*}}$ (D), Stephen Kershaw ${ }^{3}$, Xiu-Cheng Tan ${ }^{1}$, Hong Liư ${ }^{1}$, Fei Li ${ }^{1}$, Cheng Shen ${ }^{1}$, Fei-Fan Lu \\ and Xue-Fei Yang ${ }^{1,2}$
}

\begin{abstract}
The reefs in the Xiannüdong Formation (Cambrian Series 2) are the oldest archaeocyathan-microbial bioconstructions in China, but the details of their microbial structures have not been previously described. However, a new section at Tangjiahe site, northern Sichuan Province, contains very well-preserved microbial fabrics that provide these details, and is described in this study. The Tangjiahe section contains three levels of reefal buildups that were constructed by a consortium of archaeocyaths and calcimicrobes in varying proportions. The lowest (oldest) reefal buildup is a calcimicrobial biostrome, possibly in the form of a wide mound with a low relief (unconfirmed due to outcrop limitation), which was formed by Epiphyton with rare small archaeocyaths, and is sandwiched by flat-pebble conglomerates. The middle reefal buildup is a high-relief calcimicrobial mound, enclosed by oolites, that was built by intergrown Renalcis and Tarthinia. Archaeocyath fossils are uncommon, and were bound into the framework by microbial carbonates. The uppermost (youngest) reefal buildup is a low-relief archaeocyathan mound lacking calcimicrobes but partly having microbially-clotted textures attached on archaeocyaths. Calcimicrobes built or aided archaeocyaths to form the framework of Tangjiahe reefs. The three buildups formed in low-energy lagoons behind ooid shoals, and the environment was nutrient-rich due to terrigenous influx from adjacent lands. Tangjiahe reefs thus resemble most Early Cambrian reefs, in settings consistent with eutrophic, calm environments, and are characterized by the domination or aid of calcimicrobial components in framework construction.
\end{abstract}

Keywords: Microbialites, Archaeocyaths, Reefs, Cambrian Series 2, Southwest China

\section{Introduction}

In the Early Cambrian, sessile animals broadly participated in the reef construction that was previously dominated by microbial communities, heralding a new reef ecosystem with elaborate trophic webs, complex organism interactions, increased niche partitioning, and high taxonomic diversity (Pratt et al. 2001). Archaeocyathan-microbial reefs, a consortium of archaeocyaths and calcimicrobes in varying proportions, characterized such ecosystem (Zhuravlev 1986; Rowland and Gangloff 1988; Sepkoski Jr. 1992; Brasier 1996; Pratt et al. 2001; Zhuravlev 2001; Rowland and

\footnotetext{
* Correspondence: thufocom@163.com

'Division of Key Laboratory of Carbonate Reservoir of CNPC, Southwest Petroleum University, Chengdu 610500, Sichuan Province, China

${ }^{2}$ Shandong Provincial Key Laboratory of Depositional Mineralization and Sedimentary Mineral, Shandong University of Science and Technology, Qingdao 266590, Shandong Province, China

Full list of author information is available at the end of the article
}

Shapiro 2002; Gandin and Debrenne 2010), which flourished for ca. 15 million years from the base of the Tommotian (Age 2) until their extinction at the top of the Toyonian (Age 4) (Rowland and Shapiro 2002; Peng et al. 2012). The oldest known reefs of this type are recorded in the Tommotian strata of the Siberian region (Zhuravlev 1986), but the oldest Chinese archaeocyathan-microbial reefs occurred in the Atdabanian Stage (Age 3), in the Mingxinsi Formation of Guizhou, and the Xiannüdong Formation of northern Sichuan and southern Shaanxi (see Yuan et al. 2001, text-fig. 2; also see Adachi et al. 2014, figs. 10, 11). Previous studies have focused on their stratigraphic significance (e.g. Yuan and Zhang 1981; Yuan et al. 2001; Yang and Yuan 2012; Yang et al. 2015), but these studies generally lack both palaeoecological and sedimentological details. However, Hicks and Rowland (2009) recently described the facies assemblages of reefs of the Xiannüdong Formation in 
Sichuan and Shaanxi, but their material was not preserved well enough for a detailed analysis of microbial components, thus the reefal framework construction was poorly understood. In this paper, we provide a comprehensive description of Xiannüdong Formation archaeocyathan-microbial buildups from well-preserved material of the previously undescribed Tangjiahe site, Sichuan Province, China, which reveals the nature of microbial components and frameworks of reefs clearly. Our aim is to fill the gap in detailed knowledge of the oldest archaeocyathan-microbial reefs in China, and to show the details of reefal framework, including microbial components for the framework construction.

\section{Geological background}

Tangjiahe section is a road cut near Gucheng village, northeast of Wangcang town in Guangyuan city, Sichuan Province (Fig. 1). It was located in the northwestern part of the Yangtze Block that occupied a large area of South China (Fig. 1). The Hannan Land, an emerged area, covering Ningqiang and southern Hanzhong situated to the north of Tangjiahe (Fig. 1), provided abundant clastic sediments to northeastern Sichuan (Yu et al. 2013). The Xiannüdong Formation developed mainly in northeastern Sichuan and southwestern Shaanxi Provinces (Xiang et al. 1999). Both the underlying Guojiaba Formation and the overlying Yanwangbian Formation are in conformable contact with the Xiannüdong Formation rocks (Xiang et al. 1999; Hicks

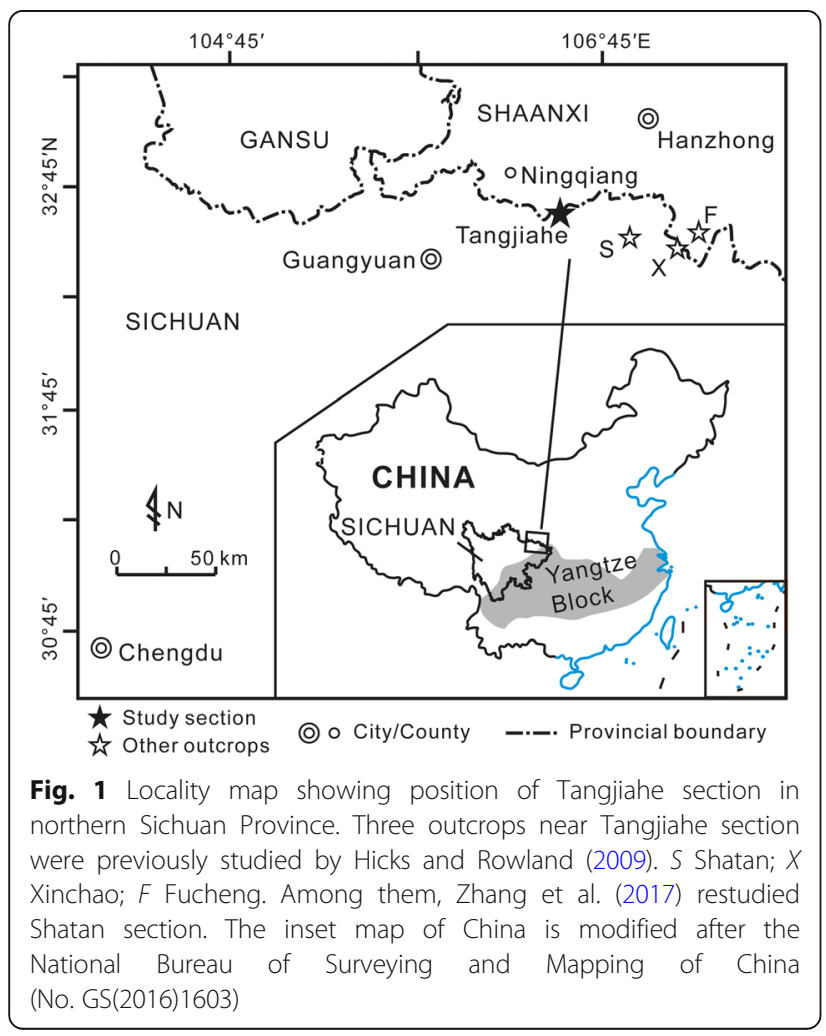

and Rowland 2009). The Xiannüdong Formation developed in Atdabanian Stage (Age 3) straddling the Qiongzhusian and Canglangpuian Stages (Yang et al. 2015).

\section{Material and methods}

Methods used in this study include field logging at the Tangjiahe section, with carefully located samples collected from the section (Fig. 2). In particular, reefal buildups and associated facies were sampled intensely. Forty-two samples were collected in total, and were made into 56 thin sections $\left(2.8 \times 4.6 \mathrm{~cm}^{2}\right), 10$ large thin sections $(9.5 \times 10.5$ $\left.\mathrm{cm}^{2}\right)$, and 5 polished slabs $\left(11.0 \times 12.5 \mathrm{~cm}^{2}\right)$. Observation and photographing of thin sections were operated with Leica DM4 P. Polished slabs were scanned by Epson V370. Thin sections and slabs are thus linked to the log, and are used to reveal details of the deposits and vertical changes through the section (Fig. 2).

\section{Stratigraphic and sedimentary succession}

The geological section at Tangjiahe site comprises bedded limestones with small reefal buildups, which occur at three levels in the succession, named as R 1, R 2 and R 3, respectively, in an ascending order. The lower part of the succession $(0-20 \mathrm{~m})$ consists of mainly gray or purple thick-bed ded conglomerates, and an intercalation of microbial biostrome ( $\mathrm{R} 1)$. The middle part $(20-70 \mathrm{~m})$ is made up of dark-gray thin- to medium-bedded silty/sandy micrite, light-gray medium- to thick-bedded oolite, and a large microbial mound ( $\mathrm{R} 2$ ) enclosed by oolite and bioclastic wackestone. The upper part $(70-100 \mathrm{~m})$ is composed of mainly gray thin- to medium-bedded oolite, thin-bedded micrite and a small archaeocyathan mound (R 3) (Fig. 2).

Flat-pebble conglomerates are medium- to thick-bed ded, $16-18 \mathrm{~m}$ thick in total. They comprise approximately parallel layers of relatively-flat pebbles of bioclastic wackestone, but within the layers the long-axis orientations of pebbles are random (Fig. 3a, b). Fossils in the bioclasticwackestone pebble are mostly small shelly fauna and archaeocyaths (Fig. 4a), representing a benthic community living in the subtidal zone with good circulation. Most archaeocyaths in pebbles are ajacicyathids (Fig. 4a, b). The matrix enclosing pebbles are micrite with abundant siliciclastic sand grains (of quartz and feldspars, with some mica), and rare bioclasts (Figs. 3b, 4a). The difference between the constitution of matrix and pebbles suggests that the latter were transported into the environment in which silty/sandy micrite deposited, rather than being the product of diagenetic processes of limestone-marl alternation (both limestone and marl contain abundant bioclasts) (Munnecke and Samtleben 1996; Westphal et al. 2008). Soft-sediment deformation, possibly induced by storm-wa ve loading, is able to form flat-pebble conglomerates, and flat-pebble conglomerate beds can often be traced laterally into undeformed beds (Chen et al. 2009; Chen and Lee 


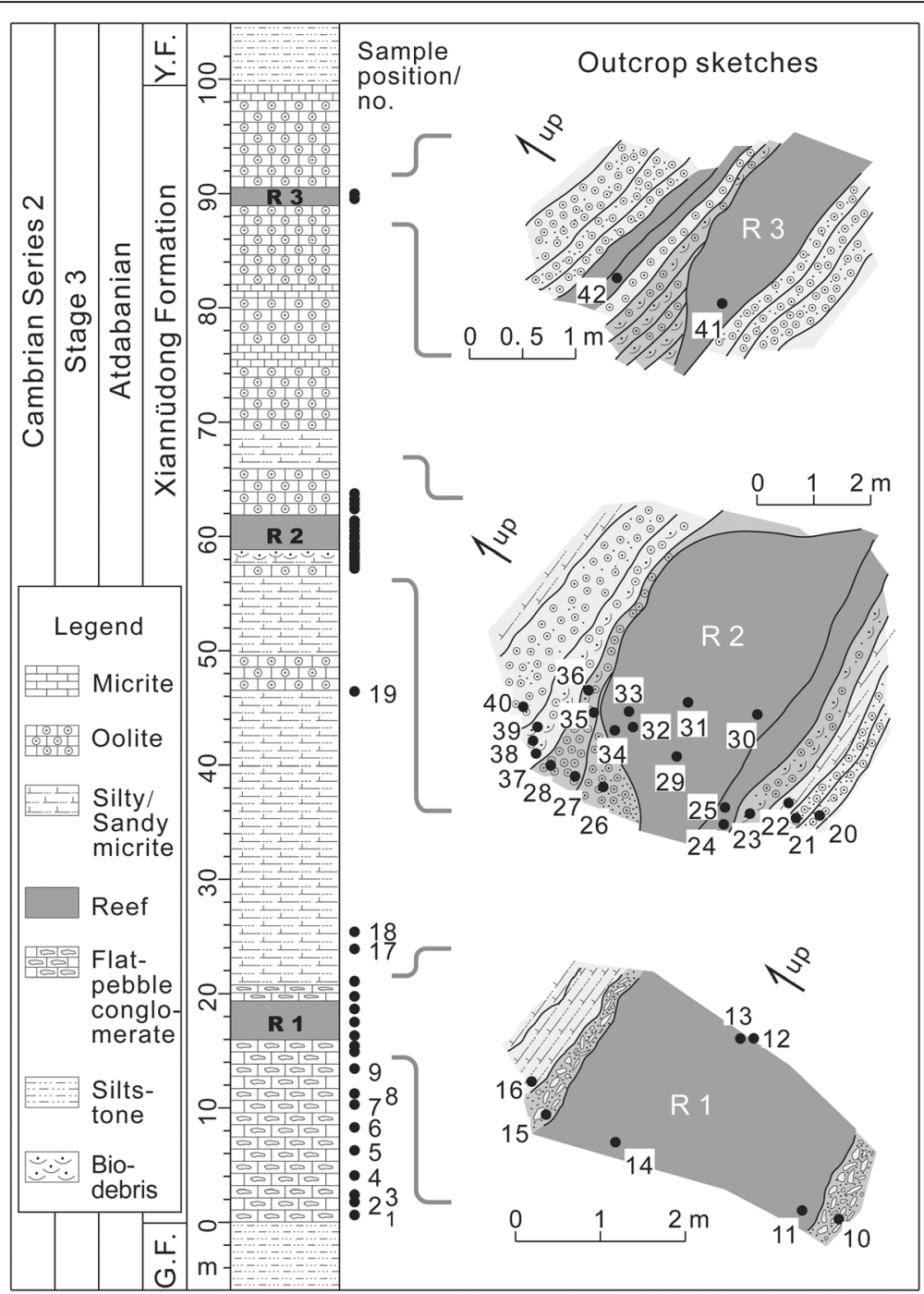

Fig. 2 Log of the Early Cambrian Tangjiahe section. Sketches of outcrop of microbialite units are shown on the right side of the lithological column. G.F. Guojiaba Formation; Y.F. Yanwangbian Formation; R 1, R 2, R 3 Reefal buildups

2013), but such a transition has not been observed at the Tangjiahe site. We interpret conglomerates in the section as storm sediments, following the idea of Sepkoski Jr. (1982), whereby rapidly cemented subtidal thin beds were eroded and redeposited to form flat pebbles. Sepkoski Jr. (1982) found flat-pebble conglomerates prevailed during the Cambrian to Early Ordovician but became rare afterwards, a fact he attributed to infaunal expansion after Ordovician radiations that resulted in bioturbation of thin beds thereby decreasing the likehood of their near-surface cementation. The evidence of storm beds in Middle to Upper Ordovician strata normally lacking flat pebbles supports this idea (e.g. Kreisa 1981). Such pebbles are generally thought to have formed above storm wave-base, such as in lagoonal (Sepkoski Jr. 1982) and subtidal environments (Wignall and Twitchett 1999).
The silty/sandy micrite is characterized by horizontal laminae, although pervasive pressure solution prevents full recognition of original sedimentary structures (Fig. 3c). The horizontal-laminated structure in fine grain sediments normally indicates a low-energy depositional environment. Under the microscope, the facies comprises siliciclastic grains with neomorphic spar (Fig. 4c). Notably, the siliciclastic grains are highly angular, but are etched, thus were affected by diagenetic dissolution, degrading textural properties (Fig. 4c). However, the presence of fresh plagioclase feldspar (Fig. 4c) is interpreted here as indicating proximity of the source material, which is consistent with the facies evidence of a shallow marine setting of the Tangjiahe site at that time, consistent with close proximity to Hannan land. The mixing of siliciclastic and carbonate sediments can occur in many environments of shallow shelf settings (Mount 1984), however, the silty/sandy micrite most likely 

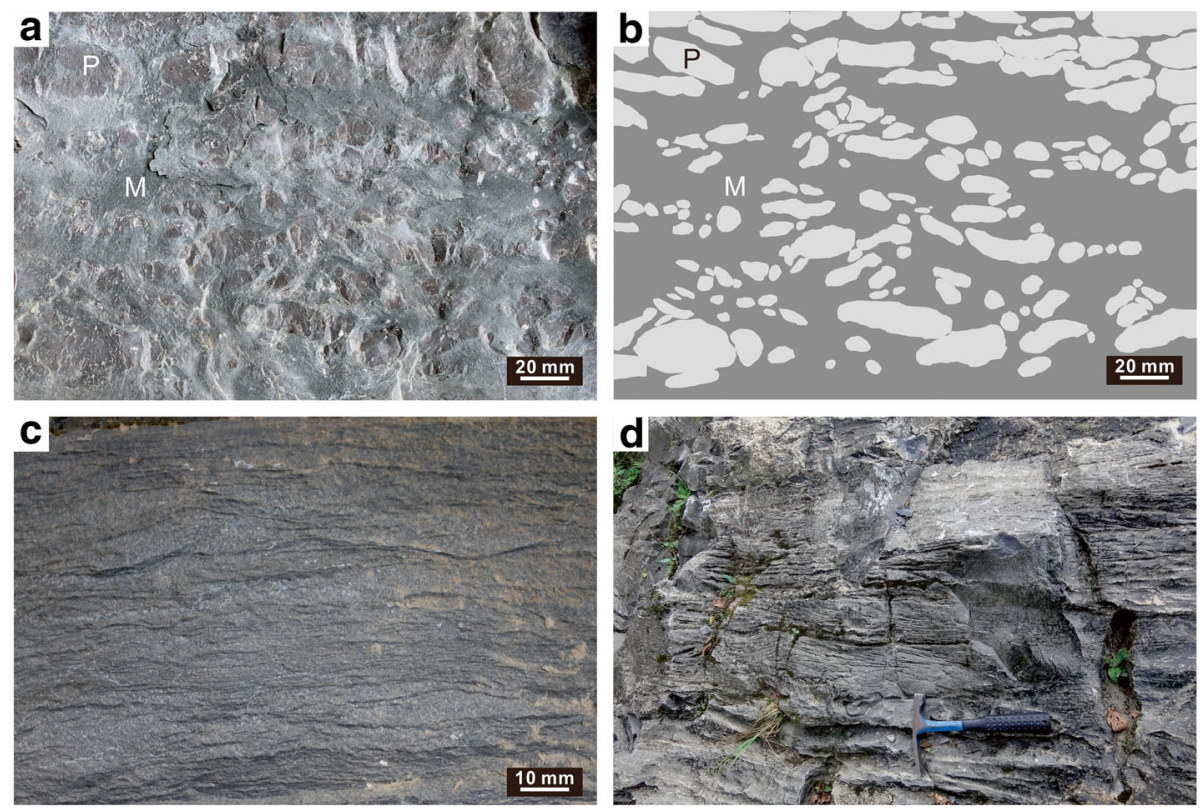

Fig. 3 a Field photo of the flat-pebble conglomerate in Tangjiahe site. Pebbles (P) are arranged in approximately parallel layers, and their longaxis orientations are random. Matrix (M) between pebbles consists of silty/sandy micrite (details shown in Fig. 4a); b Tracing of (a). P Pebble; $M$ Matrix; c The field photo of silty/sandy micrite bed. Laminae of silty/sandy micrite are mostly horizontal, but pervasive pressure solution prevents recognition of original sedimentary structures; d Field photo of oolite in Tangjiahe site, which is characterized by cross-bedding

occurred in a quiet depositional environment, such as lagoons behind shoals, due to the presence of horizontal lamination in the facies and close association with ooid shoal beds.

Oolite dominates the middle and upper part of the succession, although several silty/sandy micrite thin beds are intercalated (Fig. 2). The oolites are cross-bedded, and have trough- and planar cross-stratification (Fig. 3d). Ooids range in diameter from $0.5 \mathrm{~mm}$ to $1.5 \mathrm{~mm}$ and show varying degrees of dissolution and dolomitization (Fig. 4e, f). Siliciclastic sands occur in the space between ooids, and are nuclei of ooids in some cases (Fig. 4d). Oolite layers onlapping the flank of reefal buildups have more large ooids and less siliciclastic grains upsection; carbonate content and ooids size increasing with the decrease of the abundance of siliciclastic grains (Fig. 4d-f), evidence that ooid shoals migrated and buried the reefal buildup gradually. The oolites of Tangjiahe site are thus interpreted as representing migrating ooid shoals. Similar to modern ooid shoals of the Bahama carbonate bank, these shoals formed in shallow, high-energy marine waters, in particular shallow subtidal above normal wave-base (Purdy 1963). Through ooid dunes moving by storms and tidies, the ooid shoal migrates and buries adjacent buildups and benthic communities (Purdy 1963).

\section{Reefal buildups characterization}

Of the three reefal buildups, R 1 is a 3-m-thick, extensive horizontal bed (Figs. 2, 5a); however, it might be a low-relief mound of large diameter with exposure constrained by limited outcrop. R 1 contains rare archaeocyaths; while irregularly-shaped aggregations of calcimicrobes built a loose but filled framework amongst which sediment was accumulated (Fig. 5b). The filled framework locally formed geopetal structures (Fig. 5b). In thin section, the calcimicrobial aggregations are revealed as Epiphyton thalli encrusted by microspar cements, and the frame infillings are shown as micrite and silicate clasts (most are quartz) (Fig. 5c, d). Epiphyton thalli are radiating, branching, solid filaments (each 100-200 $\mu \mathrm{m}$ long) in longitudinal section (Fig. 5e), appearing as masses of small solid spheres (each ca. $60 \mu \mathrm{m}$ in diameter) in transverse section (Fig. 5f). They normally grew radially from the interior, to produce semi-closed irregular or spherical micro-frameworks with diameters of $1-2 \mathrm{~mm}$, by means of branching repeatedly and accumulating upwards (Fig. 5c, d). The microspar cement enclosing thalli does not contain any siliciclastic grains (Fig. 5e, f), indicating its formation prior to burial of sediments. The cement is thus interpreted to have formed along with the calcification of Epiphyton, and make the micro-framework solid and stable. The matrix (silty/sandy micrite) of $\mathrm{R} 1$ is consistent with formation in lagoons behind shoals, thus $\mathrm{R} 1$ presumably developed during a break between storm events, given that it was sandwiched by conglomerate beds.

$\mathrm{R} 2$ is a $2.7-\mathrm{m}$-thick, 6 -m-wide calcimicrobial mound enclosed by oolites (Figs. 2, 6a). The mound flank is onlapped by middle- to thick-bedded oolites with a sharp 

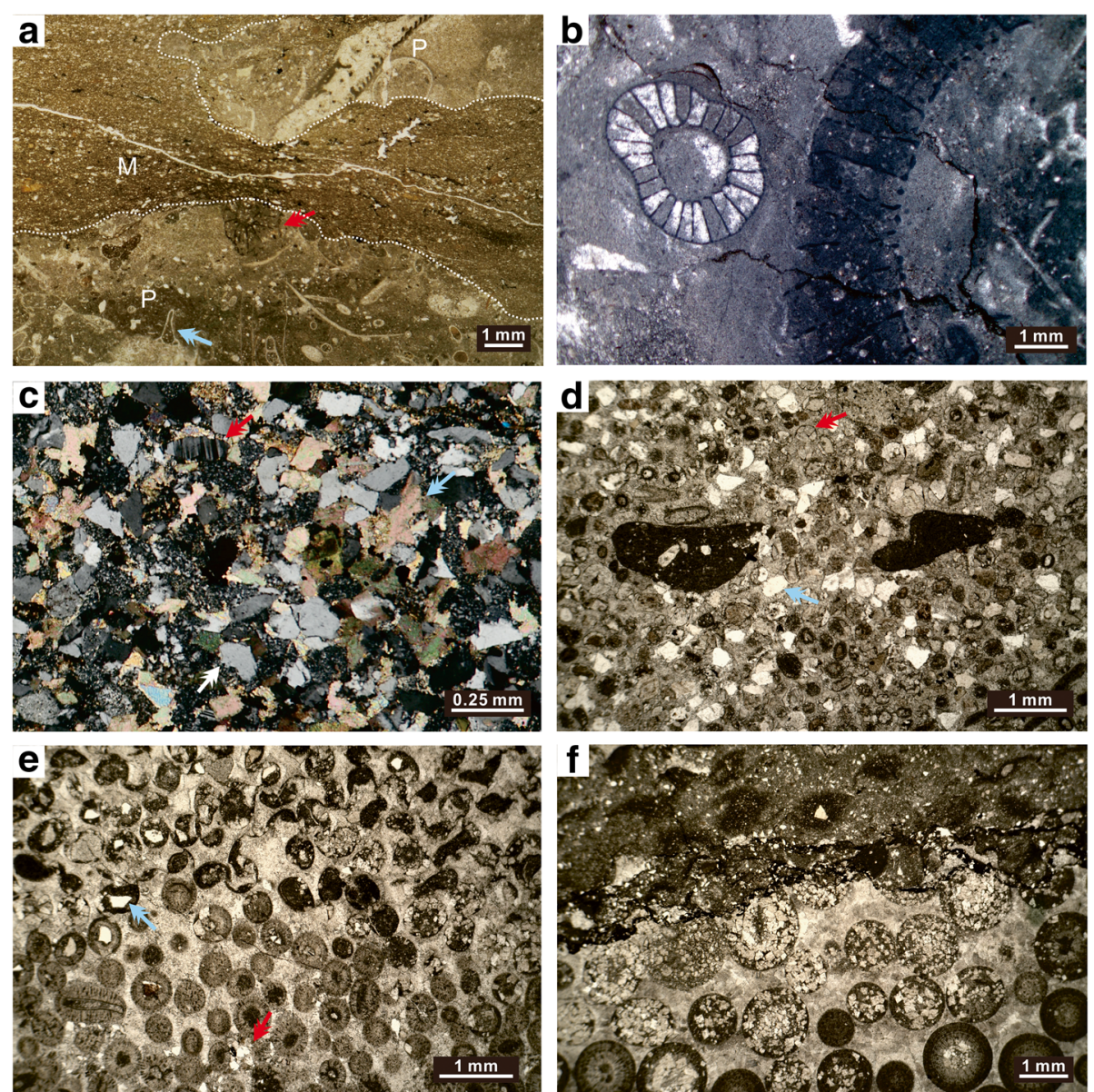

Fig. 4 a Photomicrograph of flat-pebble conglomerates. Pebbles (P) of conglomerate, Sample 10 (Fig. 2), comprise bioclastic wackestone and are surrounded by micrite and siliciclastic matrix (M). Most bioclasts are fossils of small shelly fauna (blue arrow) and archaeocyaths (red arrow). Small shelly fauna are mainly chancelleries and hyolithids; b Photomicrograph of archaeocyathan fossils in pebbles, taken under plane-polarized light (PPL). Dailycyathus sp. (left); Nochoroicyathus sp. (right); c Photomicrograph of silty/sandy micrite, taken under cross-polarized light (XPL). Silty/ sandy micrite, Sample 17 (Fig. 2), mostly comprises neomorphic spar and angular but etched siliciclastic grains, such as feldspar (red arrow) and quartz (white arrow); $\mathbf{d}$-f Photomicrographs (PPL) of the oolite show that ooids become larger while siliciclastic grains become less abundant upsection, and are cemented by calcite spar. Among these three photos, ooids in photo $\mathbf{d}$ (red arrow) are smallest, approximately equal to silicate clasts were not only deposited in the space between ooids (red arrow), but also were the nuclei of ooids (blue arrow). Sample numbers of these three photos are respectively 26, 27 and 28 in Fig. 2

contact (Figs. 2, 6a). The framework of $\mathrm{R} 2$ was built by aggregations of calcimicrobes consisting mainly of Renalcis, Tarthinia and a few Epiphyton (Fig. 6b-d). Aggregations are fan-shaped, upward expanding tufted, in which Renalcis were intergrown with Tarthinia (normally the latter surrounded the former) (Fig. 6b, c). Renalcis thalli, each up to several millimeters across, are branching, and consist of aggregates of lunate, to equant, to reniform, to irregular chambers (Fig. 6d-f). The chamber wall, 40 to $60 \mu \mathrm{m}$ thick, is micritic, sharp-surfaced, and has V-shaped clefts piercing their thick walls in some cases (Fig. 6d-f). Tarthinia resembles Renalcis in appearance of external morphology, but the internal organization is not divided into separate compartments, and the wall $(100-150 \mu \mathrm{m}$ thick) is fibrous, much thicker and characterized by vague inner surfaces (Fig. 6f). Encrusted aggregations made by Renalcis and Tarthinia provide the substrate for the growth of later generations of calcimicrobes (Fig. 6b, c). Archaeocyathan fossils are present but not common in the framework (Fig. 6b). They are identified as Metacyathellus lepidus (Yuan and Zhang) and less abundant Erismacoscinus zunyiensis (Yuan) (Fig. 6g, h). Most archaeocyaths are bound by calcimicrobes forming parts of the framework (Fig. 6b). Thus calcimicrobes can be observed to have initiated on archaeocyaths in some places (Fig. 6b, c), but because archaeocyaths are not common, and with little presence of bioclasts, the calcimicrobial aggregations must have formed on the sediment surface. It is not clear that to what extent the sediment surfaces were lithified prior to calcimicrobial initiation and growth, 

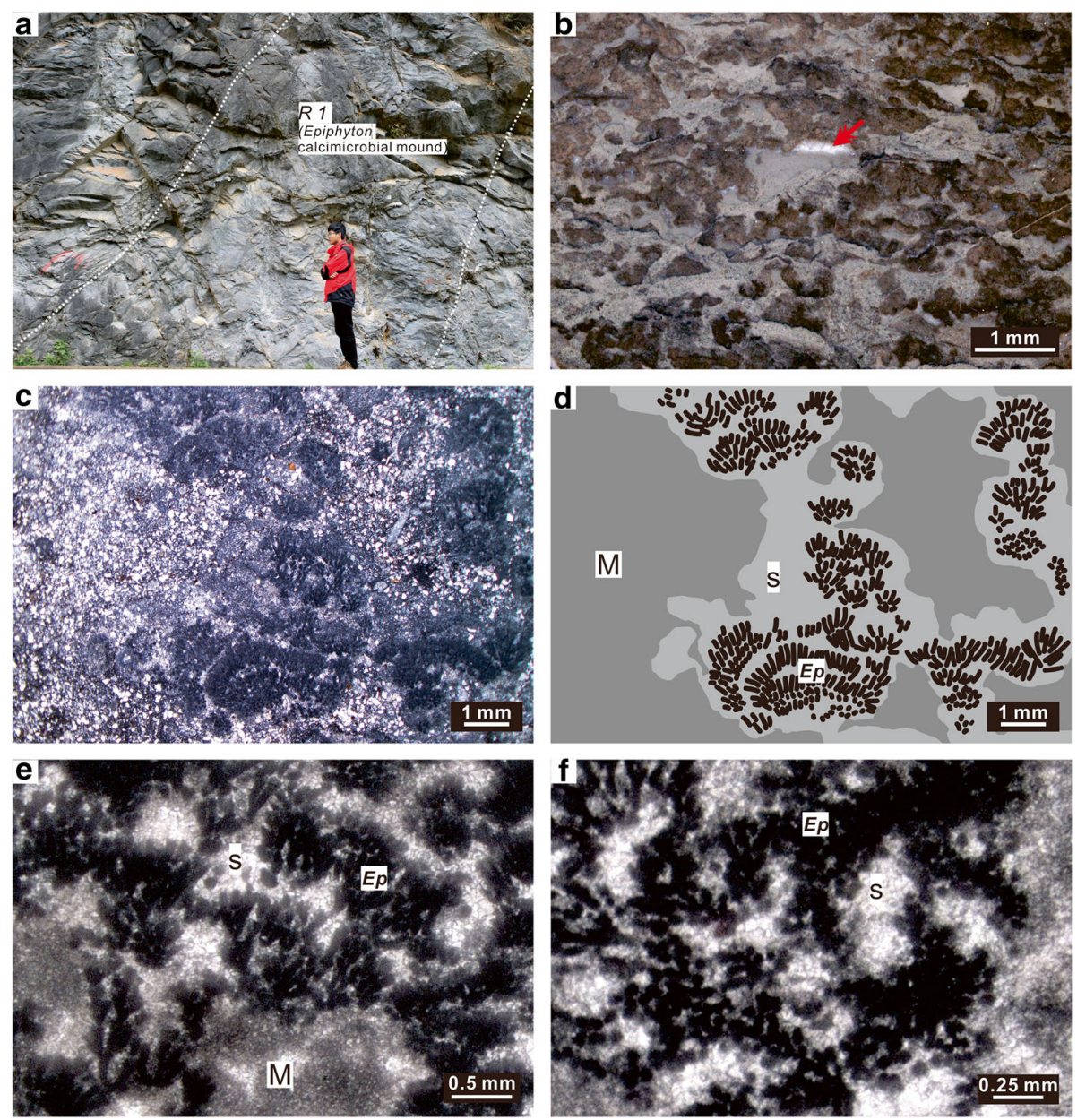

Fig. 5 a Field photo of R 1 shows that it is an extensive horizontal bed or low-relief mound with a large diameter. The man as scale is $1.8 \mathrm{~m}$ high; $\mathbf{b}$ The polished slab (Sample 14 in Fig. 2) of R 1 shows the frame was built by irregularly-shaped aggregations of Epiphyton thalli (darkercolor parts). The frame was filled with silty/sandy micrite (lighter-color parts) but had geopetal structure (red arrow) locally; c-d Photomicrographs (PPL) of R 2 framework built by Epiphyton (Ep) thalli (Sample 14 in Fig. 2). (d) is the tracing of (c). Microspar cements (s) encrusted aggregates of Epiphyton (Ep) thalli. Microspar contains few silicate grains. The space between Epiphyton aggregations is filled with silty/sandy micrite (M); e Photomicrograph (PPL) of Epiphyton (Ep) thalli in longitude section (Sample 14 in Fig. 2). The morphology is shown as fan-shaped clusters of branching filaments. Spars (s) filled the space between Epiphyton (Ep) thalli; $\mathbf{f}$ Photomicrograph (PPL) shows Epiphyton (Ep) thalli in transverse section as aggregation of solid dots. Spars (s) filled the space between Epiphyton (Ep) thalli (Sample 14 in Fig. 2)

but is obvious that the calcimicrobial reefs were built principally from the microbial fabrics, and archaeocyaths are subordinate. Similar to the R 1 , the sediment among R 2 framework consists of silty/sandy micrite, which evidences that the thrombolite mound likely formed in a lagoon behind ooid shoals.

R 3 is a ca. 1-m-thick, 3-m-wide, low-relief archaeocyathan mound. Its flank was onlapped by thin oolite beds with a sharp contact (Figs. 2, 7a). Contrasting with the two older buildups, R 3 lacks calcimicrobes but has abundant archaeocyaths, nearly all of which are Metacyathellus lepidus (Yuan and Zhang) (Fig. 7c). Most archaeocyathan fossils are intact; and the exquisite morphology is preserved very well, indicating almost in-situ occurrence (Fig. 7b). Archaeocyaths are mainly matrix-supported, while some mutually-supported, or in contact through twined tersoids (Fig. 7b, c). Thus the outer walls and tersoids of archaeocyaths locally formed shelter-cavities possessing geopetal infilling (Fig. 7b, d, e). Despite the lack of calcimicrobes, tersoids and undersides of shelter cavities are locally attached by clotted micrite fabrics that are probably microbial in origin (Fig. 7d). Therefore, archaeocyaths of R 3 presumably constructed the mound by baffling fine sediments in currents, and the twined tersoids and clotted fabrics might enhance the baffling of archaeocyaths. Given the framework matrix and flanking facies similar to those of R 2, R 3 might be a patch reef that formed in a lagoon and then was buried by migrating ooid shoals. 

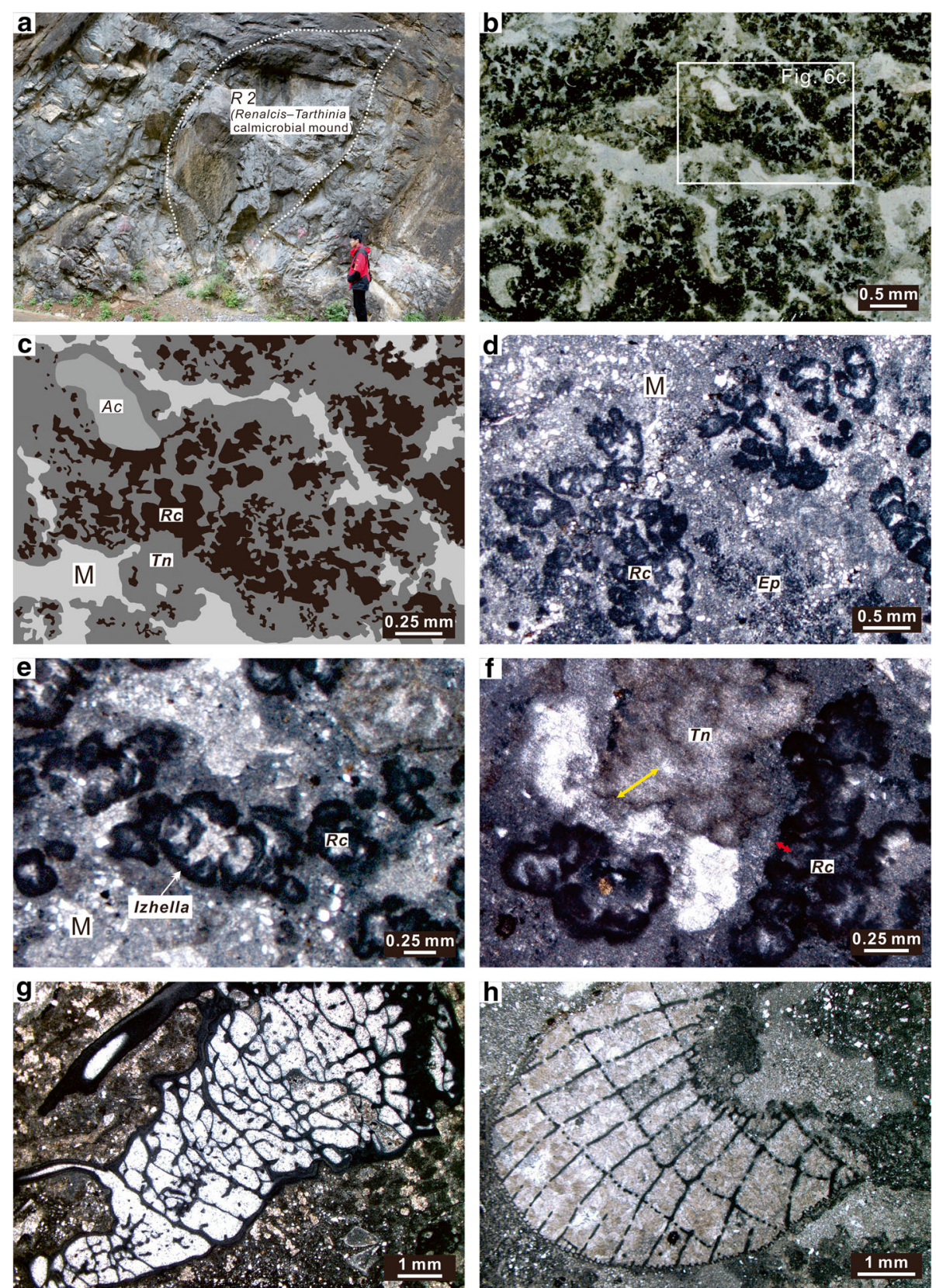

Fig. 6 a Photo of R 2 in the field. R 2 mound is onlapped by oolite beds in the flank. The man as scale is $1.8 \mathrm{~m}$ in height; $\mathbf{b}$ A polished slab (Sample 29 in Fig. 2) shows that the aggregations of calcimicrobes building the frame are fan-shaped and were encrusted by sediments; $\mathbf{c}$ The close-up of rectangle area in (b). Renalcis $(R c)$ intergrew with Tarthinia $(T n)$, and normally the latter surrounded the former. Archaeocyaths $(A c)$ are not common in presence. The space between calcimicrobial aggregations is filled with silty/sandy micrite (M); d Photomicrograph (PPL) shows that Renalcis thalli are branching and chambered. The chamber varies in morphology from lunate, to equant, to reniform, to irregular. A few Epiphyton (Ep) thalli are in presence in the framework as well; e Photomicrograph (PPL) shows that some thalli have V-shaped clefts piercing their thick walls, and are Izhella, distinguished from Renalcis (Rc). Sample 30 in Fig. 2; f Photomicrograph (PPL) shows that Tarthinia (Tn) thallus is similar to Renalcis (Rc), but its wall (yellow arrow) is much thicker than the latter (red arrow), and characterized by vague inner surfaces. Sample 32 in Fig. 2; g Photomicrograph (PPL) of Metacyathellus lepidus (Yuan and Zhang). Sample 29 in Fig. 2; h Photomicrograph (PPL) of Erismacoscinus zunyiensis (Yuan). Sample 32 in Fig. 2

Based on the above analysis of depositing features of archaeocyathan-microbial succession, we proposed a sedimentary model for the Tangjiahe reefs as shown in
Fig. 8. Relatively large-scale shoals, characterized by cross-bedded oolites, provided barriers for lagoons with low-energy depositional environments (Fig. 8). However, 

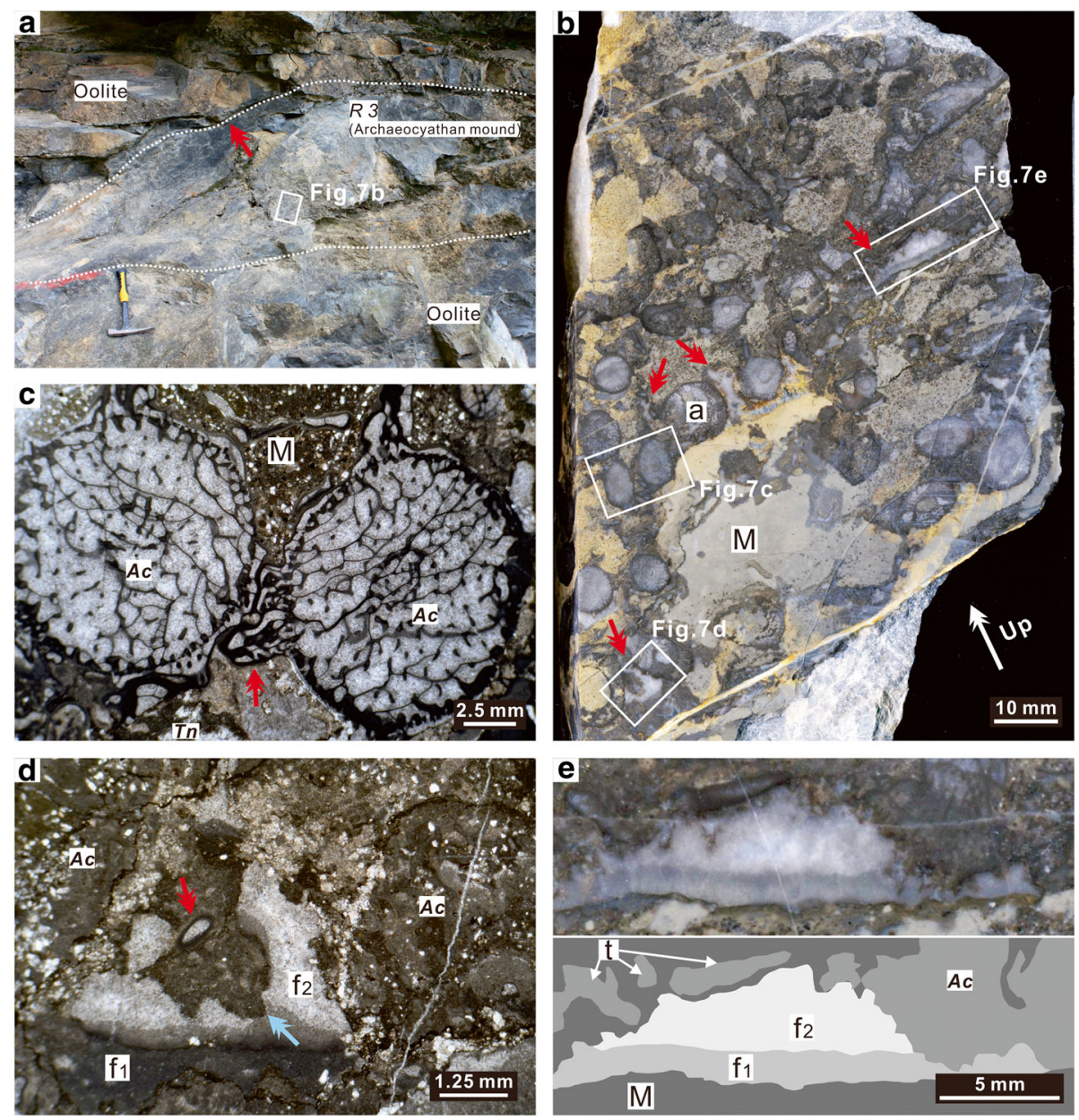

Fig. 7 a Field photo of R 3 shows oolite beds onlapped the reef-mound flank with a sharp contact (red arrow). Hammer length =30 cm; $\mathbf{b}$ Polished slab shows archaeocyaths (Ac) are abundant and intact. Scattered archaeocyaths were linked weakly to form a porous and loose framework. Locally adjacent archaeocyaths and their tersoids developed cavities having geopetal structure (red arrows). Micrite and siliciclastics deposited among the framework. Sample 45 in Fig. 2; c Photomicrograph (PPL) shows the close-up of rectangle area (marked as Fig. 7c) in (b). Two archaeocyathan fossils (Ac) were bound by tersoids twining (red arrow). The silty/sandy micrite (M) deposited between archaeocyaths; $\mathbf{d}$ Photomicrograph (PPL) shows the close-up of rectangle area (marked as Fig. 7d) in (b). A cavity was formed by adjacent archaeocyaths and possibly microbial clotted texture attached on tersoids. Geopetal structure developed in the cavity, and is comprised of spar cements (upper part, f2) and micrite sediments (lower part, f1); e The close-up of a rectangle area (marked as (Fig. 7e) in (b) shows a cavity like stromatactis which was formed by archaeocyaths and tersoids. The lower part of (e) is the tracing of the upper part

the environment, from shoreface to upper offshore, was presumably well-illuminated with good water-circulation, so that subtidal benthic metazoans (most are archaeocyaths and small shelly faunas) proliferated well and provided abundant material for the sedimentation of bioclastic packto wackestones in the offshore zone (Figs. 4, 8). During stormy events, the offshore bioclastic carbonates are interpreted to have been eroded into pebbles, then transported to low-energy environments (e.g. back lagoons; lower offshore positions), and eventually deposited there as conglomerate facies (Figs. 4, 8). Thus, under this interpretation, R 1 intercalated into conglomerates would form during the calm period between two high-energy storm events (Fig. 2). Storm waves and tidal currents are both able to migrate ooid shoals by moving ooid dunes. These migrating ooid shoals are interpreted to have buried adjacent reefal buildups such as R 2 and R 3, as shown in the reefal flank facies that they were onlapped by oolite beds (Figs. 2, 8). The rising of sea level does not account for the growth of reefs at Tangjiahe site, because occurrences of reefs were not correlated in sections of Tangjiahe, Shatan, Xinchao and Fucheng (Hicks and Rowland 2009); if the reef facies represented an abrupt rise of sea level, then one might expect to see it synchronously occurring in all those sections.

\section{Discussion}

Our model is consistent with that of Hicks and Rowland (2009), which was based on data from Shatan, Fucheng 


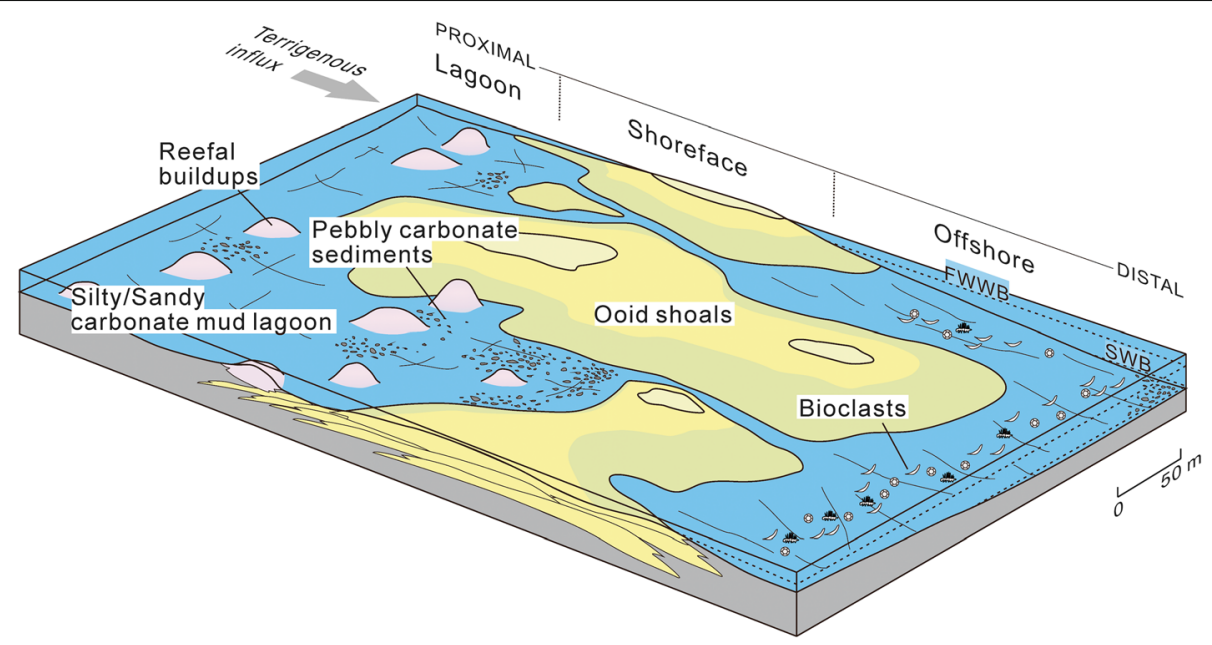

Fig. 8 Reconstruction of the sedimentary environment of the Xiannüdong Formation reefs at Tangjiahe site. See details in text. FWWB Fair weather wave-base; SWB Storm wave-base

and Xinchao sections (Fig. 1). Although Hicks and Rowland (2009) did not record any conglomerates, recently Zhang et al. (2017) documented this facies on the upper part of Shatan section. In summary, our sedimentological interpretation suggests the lagoon behind ooid shoals was an optimum environment for the development of Tangjiahe reefs.

In a wider context, Cambrian reefs actually spread over a wide spectrum of environments (Zhuravlev 2001 and references therein). Nevertheless, most reefs built by Renalcis, Epiphyton, Girvanella, and Tarthinia associations were found in fine-grained sediments indicating calmer settings (Zhuravlev 2001 and references therein). Probably, such calcimicrobes lacked the ability to resist high-energy waves, as evidenced by community change when reefs developed across a water depth gradient. For instance, ajacicyathidRenalcis-Epiphyton associations commonly turned into a pure Razumovskia crust when a reef top reached the fair-weather wave-base (Zhuravlev and Gravestock 1994). This is consistent with the occurrence of R 1 and R 2 in lagoons behind shoals, which were built mainly of Epiphyton and Renalcis-Tarthinia respectively (Figs. 5, 6).

The reason why $\mathrm{R} 3$ formed in a calm environment might be that the loose framework by Metacyathellus lepidus was not able to resist high-energy currents. This is confirmed by the archaeocyathan reef at the Aldan River, Siberia, where the main framebuilders (Cambrocyathellus) are modular, bowl-shape and much larger than Metacyathellus lepidus (Riding and Zhuravlev 1995). Their modular organization is of fused individuals to build a rigid framework, among which matrix sediment is pack -/wackestone containing abundant and various metazoan skeletons (Riding and Zhuravlev 1995). The Aldan River reefs, unlike Tangjiahe reefs, formed in an open, agitated environment having a good water circulation.
The lagoon received terrigenous influx due to proximity of the land, which might be another reason for the habitat preference of Tangjiahe reefs. Unlike most modern sponges living in oligotrophic environments, archaeocyaths presumably lacked photosynthetic symbionts, thus they preferred to inhabit turbid water bearing organic matter and plankton (Wood et al. 1993; Riding and Zhuravlev 1995; Zhuravlev 2001). Archaeocyaths are more abundant in environments with siliciclastic input in many regions, such as Siberia (Riding and Zhuravlev 1995), Sardinia (Debrenne et al. 1993), and western Mongolia (Wood et al. 1993). Terrigenous supply resulted in nutrient-rich seawater, so that archaeocyaths were able to gain enough food through filter-feeding. Also archaeocyaths normally have a particular morphology to resist high sedimentation rate and prevent infiltration of mud (Riding and Zhuravlev 1995). In addition, calcimicrobes seem to have preferred nutrient-rich environments as well. For instance, as important components in the Devonian reef system, calcimicrobes and microbial fabrics basically occurred in mesotrophic and eutrophic seawater (MacNeil and Jones 2008). Thus, from a view of trophic preference, the occurrence of the Tangjiahe reefs, consisting mainly of archaeocyaths and calcimicrobes, in lagoons, is consistent with the range of evidence of their preferred life modes.

Hicks and Rowland (2009) and Zhang et al. (2017) documented several archaeocyathan-microbial reefs of the Xiannüdong Formation in areas close to our study section (Fig. 1). However, the authors were not able to describe the microbial components in detail because of the poor preservation of their materials (Hicks and Rowland 2009; Zhang et al. 2017). Adachi et al. (2014) re-examined the framework of well-preserved archaeocyathan-microbial reefs in the Tianheban Formation, Hubei, South China, which are the youngest archaeocyathan-microbial reefs in 
South China and were previously reported by Debrenne et al. (1991) and Zhang and Yuan (1994). Tianheban reefs are composed of mainly Archaeocyathus yichangensis, Epiphyton, Renalcis, and Girvanella. A. yichangensis constructed the framework-like scaffolders, and baffled sediments from currents to prevent calcimicrobes from being buried. In turn, calcimicrobes, which lived in spaces between archaeocyaths, attached to the archaeocyaths and reinforced the framework (Adachi et al. 2014). However, our results reveal that Tangjiahe calcimicrobes did not collaborate with archaeocyaths very well in the formation of a reefal framework; $\mathrm{R} 1$ and $\mathrm{R} 2$ have rare or a few archaeocyaths in the framework, and there was no calcimicrobes in R 3, except for a few clotted fabrics attached to archaeocyaths. The hypothesis of Zhuravlev (1996) that it might be caused by calcimicrobial poison inhibiting archaeocyathan growth cannot be upheld for cases in which both archaeocyaths and calcimicrobes are abundant, and interacted with each other to form the framework (e.g. Riding and Zhuravlev 1995; Adachi et al. 2014).

Although archaeocyaths contributed to reef construction, calcimicrobes were likely the core of Early Cambrian reefal buildups. They either formed microbialite reefs with rare metazoans (e.g. R 1 and R 2 in Tangjiahe; reefs in Hicks and Rowland 2009), or cooperated with archaeocyaths to stabilize the framework (e.g. Riding and Zhuravlev 1995; Adachi et al. 2014). However, many Early Cambrian reefs lacked archaeocyaths and none contained more than $50 \%$ archaeocyath skeleton by volume (Rowland and Gangloff 1988). Gandin and Debrenne (2010) compiled data from more than 50 Early Cambrian reefs worldwide and found that nearly half of them are dominated by microbes in the framework construction, whereas archaeocyaths are dominant framebuilders of $1 / 3$ reefs (whose framework construction was aided by subdominant microbes). Hence, archaeocyaths were important contributors to Early Cambrian reef relief, but calcimicrobes were more essential to reef accretion. Following a major decline in archaeocyaths at the end of the Early Cambrian, Middle to Late Cambrian reefs were dominated by thrombolite and stromatolite with few skeletal metazoans of any kind (Zhuravlev 1996; Lee et al. 2015), although several lithistid spongemicrobial reefs in Middle-Late Cambrian have been reported recently (Hong et al. 2012, 2016; Adachi et al. 2015; Lee et al. 2016; Lee and Riding 2018).

\section{Conclusions}

1) The Xiannüdong Formation in Tangjiahe section contains three levels of reefal buildups, named R 1, R 2 and $\mathrm{R} 3$ in an ascending order. R 1 is a calcimicrobial biostrome or wide mound with low-relief, which is formed by Epiphyton and sandwiched by flat-pebble conglomerate beds. R 2 is a high-relief calcimicrobial mound enclosed by oolite beds, and was built by aggregations of intergrown Renalcis and Tarthinia. Archaeocyaths are uncommon, and were bound into the framework. R 3 is a low-relief archaeocyathan mound lacking calcimicrobes but having probably microbial clotted textures.

2) The three reefal buildups presumably formed in lagoons with calm conditions due to the protection of ooid shoals, and are nutrient-rich because of terrigenous input from adjacent lands. Tangjiahe reefs are similar to most Early Cambrian reefs, in settings consistent with nutrient-rich, less agitated subtidal environments, characterized by the domination or aid of calcimicrobial components in framework construction.

\section{Abbreviations}

FWWB: Fair weather wave-base; SWB: Storm wave-base

\section{Acknowledgements}

We thank Andrey Y. Zhuravlev for the identification of archaeocyathan fossils, and his work significantly improved this manuscript. We thank Yong-Biao Wang for his constructive comments. We thank Robert Burne, Markus Aretz, and Ya-Sheng Wu for their reviews which improved the manuscript. The research is supported by National Natural Science Foundation of China (41602166), National Scientific and Technology Major Project (2016ZX05004 002-001), PetroChina Innovation Fund (2018D-5007-0105), Scientific Research Starting Project of SWPU (2017QHZ005) and Shandong Provincial Key Laboratory of Depositional Mineralization (DMsMzO1TO35).

\section{Authors' contributions}

HT conceived the study, and drafted the manuscript. SK made thin sections and polished slabs, and helped to draft the manuscript. All authors participated in the field work, and approved the final manuscript.

\section{Competing interests}

The authors declare that they have no competing interests.

\section{Publisher's Note}

Springer Nature remains neutral with regard to jurisdictional claims in published maps and institutional affiliations.

\section{Author details}

'Division of Key Laboratory of Carbonate Reservoir of CNPC, Southwest Petroleum University, Chengdu 610500, Sichuan Province, China. ${ }^{2}$ Shandong Provincial Key Laboratory of Depositional Mineralization and Sedimentary Mineral, Shandong University of Science and Technology, Qingdao 266590, Shandong Province, China. ${ }^{3}$ Department of Life Sciences, Brunel University, Kingston Lane, Uxbridge UB8 3PH, UK.

Received: 23 April 2018 Accepted: 24 October 2018

Published online: 27 February 2019

\section{References}

Adachi, N., A. Kotani, Y. Ezaki, and J.B. Liu. 2015. Cambrian series 3 lithistid sponge-microbial reefs in Shandong Province, North China: Reef development after the disappearance of archaeocyaths. Lethaia 48 (3): 405-416.

Adachi, N., T. Nakai, Y. Ezaki, and J.B. Liu. 2014. Late early Cambrian archaeocyath reefs in Hubei Province, South China: modes of construction during their period of demise. Facies 60 (2): 703-717.

Brasier, M.D. 1996. The basal Cambrian transition and Cambrian bio-events (from terminal Proterozoic extinctions to Cambrian biomeres). In Global events and event stratigraphy in the Phanerozoic, ed. O.H. Walliser, 113-138. Berlin: Springer.

Chen, J., and H.S. Lee. 2013. Soft-sediment deformation structures in Cambrian siliciclastic and carbonate storm deposits (Shandong Province, China): Differential liquefaction and fluidization triggered by storm-wave loading. Sedimentary Geology 288: 81-94. 
Chen, J.T., S.K. Chough, S.S. Chun, and Z.Z. Han. 2009. Limestone pseudoconglomerates in the late Cambrian Gushan and Chaomidian formations (Shandong Province, China): soft-sediment deformation induced by storm-wave loading. Sedimentology 56 (4): 1174-1195.

Debrenne, F., A. Gandin, and M. Debrenne. 1993. Calcaires à archéocyathes du Membre de la vallée de Matoppa (Formation de Nebida), Cambrien inférieur du Sud-Ouest de la Sardaigne (Italie). Annales de Paleontologie 79: 77-118.

Debrenne, F., A. Gandin, and A. Zhuravlev. 1991. Paleoecological and sedimentological remarks on some lower Cambrian sediments of the Yangtse platform (China). Bulletin de la Société Géologique de France 162: 575-583.

Gandin, A., and F. Debrenne. 2010. Distribution of the archaeocyathcalcimicrobial bioconstructions on the early Cambrian shelves. Palaeoworld 19 (3-4): 222-241.

Hicks, M., and S.M. Rowland. 2009. Early Cambrian microbial reefs, archaeocyathan inter-reef communities, and associated facies of the Yangtze platform. Palaeogeography, Palaeoclimatology, Palaeoecology 281 (1-2): 137-153.

Hong, J., S.-H. Cho, S.-J. Choh, J. Woo, and D.-J. Lee. 2012. Middle Cambrian siliceous sponge-calcimicrobe buildups (Daegi Formation, Korea): Metazoan buildup constituents in the aftermath of the Early Cambrian extinction event. Sedimentary Geology 253-254: 47-57.

Hong, J., J.H. Lee, S.-J. Choh, and D.-J. Lee. 2016. Cambrian series 3 carbonate platform of Korea dominated by microbial-sponge reefs. Sedimentary Geology 341: 58-69.

Kreisa, R.D. 1981. Storm-generated sedimentary structures in subtidal marine facies with examples from the middle and upper Ordovician of southwestern Virginia. Journal of Sedimentary Petrology 51 (3): 823-848.

Lee, J.-H., J.T. Chen, and S.K. Chough. 2015. The middle-late Cambrian reef transition and related geological events: A review and new view. EarthScience Reviews 145: 66-84.

Lee, J.-H., J. Hong, S.-J. Choh, D.-J. Lee, J. Woo, and R. Riding. 2016. Early recovery of sponge framework reefs after Cambrian archaeocyath extinction: Zhangxia formation (early Cambrian series 3), Shandong, North China. Palaeogeography, Palaeoclimatology, Palaeoecology 457: 269-276.

Lee, J.-H., and R. Riding. 2018. Marine oxygenation, lithistid sponges, and the early history of Paleozoic skeletal reefs. Earth-Science Reviews 181: 98121

MacNeil, A.J., and B. Jones. 2008. Nutrient-gradient controls on Devonian reefs: Insight from the ramp-situated Alexandra reef system (Frasnian), Northwest Territories, Canada. In Controls on Carbonate Platform and Reef Development. SEPM Special Publications, ed. J. Lukasik and J.A. Simo, vol. 89, 271-289.

Mount, J.F. 1984. Mixing of siliciclastic and carbonate sediments in shallow shelf environments. Geology 12 (7): 432-435.

Munnecke, A., and C. Samtleben. 1996. The formation of micritic limestones and the development of limestone-marl alternations in the Silurian of Gotland, Sweden. Facies 34 (1): 159-176.

Peng, S., L.E. Babcock, and R.A. Cooper. 2012. Chapter 19 - The Cambrian period. In The geologic time scale, ed. F.M. Gradstein, J.G. Ogg, M.D. Schmitz, and G.M. Ogg, 437-488. Boston: Elsevier.

Pratt, B.R., B.R. Spincer, R.A. Wood, and A.Y. Zhuravlev. 2001. Ecology and evolution of Cambrian reefs. In The critical moments in Paleobiology and earth history series, 254-274. New York: Columbia University Press.

Purdy, E.G. 1963. Recent calcium carbonate facies of the great Bahama Bank. 2. Sedimentary facies. The Journal of Geology 71 (4): 472-497.

Riding, R., and A.Y. Zhuravlev. 1995. Structure and diversity of oldest sponge-microbe reefs: Lower Cambrian, Aldan River, Siberia. Geology 23 (7): 649-652.

Rowland, S.M., and R.A. Gangloff. 1988. Structure and paleoecology of lower Cambrian reefs. Palaios 3 (2): 111-135.

Rowland, S.M., and R.S. Shapiro. 2002. Reef patterns and environmental influences in the Cambrian and earliest Ordovician. In Phanerozoic Reef Patterns, ed. W. Kiessling, E. Flügel, and J. Golonka, vol. 72, 95-128. Tulsa: Society of Economic Paleontologists and Mineralogists. SEPM Special Publications

Sepkoski Jr., J.J. 1982. Flat-pebble conglomerates, storm deposits, and the Cambrian bottom fauna. In Cyclic and event stratification, ed. G. Einsele and A. Seilacher, 371-385. Berlin: Springer-Verlag.
Sepkoski Jr., J.J. 1992. Proterozoic-early Cambrian diversification of metazoans and metaphytes. In The Proterozoic biosphere, ed. J.W. Schopf and C. Klein, 553-561. Cambridge: Cambridge University Press.

Westphal, H., A. Munnecke, F. Böhm, and S. Bornholdt. 2008. Limestone-marl alternations in epeiric sea settings - Witnesses of environmental changes, or of rhythmic diagenesis? Geological Association of Canada Special Paper 48: 389-406.

Wignall, P.B., and R.J. Twitchett. 1999. Unusual intraclastic limestones in lower Triassic carbonates and their bearing on the aftermath of the end-Permian mass extinction. Sedimentology 46 (2): 303-316.

Wood, R., A.Y. Zhuravlev, and C.T. Anaaz. 1993. The ecology of lower Cambrian buildups from Zuune arts, Mongolia: Implications for early metazoan reef evolution. Sedimentology 40 (5): 829-858.

Xiang, L., Z. Zhu, S. Li, and Z. Zhou. 1999. Stratigraphic dictionary of China: Cambrian. Beiijing: Geological Publishing House (in Chinese).

Yang, A.H., and K.X. Yuan. 2012. New archaeocyaths from the early Cambrian of Shaanxi and Guizhou provinces, South China. Geobios 45 (6): 591-601.

Yang, A.H., M.Y. Zhu, A.Y. Zhuravlev, K.X. Yuan, J.M. Zhang, and Y.Q. Chen. 2015. Archaeocyathan zonation of the Yangtze platform: Implications for regional and global correlation of lower Cambrian stages. Geological Magazine 153 (3): 388-409.

Yu, K.H., Z.K. Jin, K. Su, X.D. Dong, W. Zhang, H.Y. Du, Y. Chen, and W.D. Zhang. 2013. The Cambrian sedimentary characteristics and their implications for oil and gas exploration in north margin of middleupper Yangtze plate. Science China Earth Sciences 56 (6): 1014-1028.

Yuan, K.X., and S.G. Zhang. 1981. Lower Cambrian archaeocyathid assemblages of central and southwestern China. GSA Special Papers 187: 39-54.

Yuan, K.X., M.Y. Zhu, J.M. Zhang, and H. Vaniten. 2001. Biostratigraphy of archaeocyathan horizons in the lower Cambrian Fucheng section, South Shaanxi Province: Implications for regional correlations and archaeocyathan evolution. Acta Palaeontologica Sinica 40 (Suppl): 115-129 in Chinese with English abstract.

Zhang, J.M., and K.X. Yuan. 1994. Archaeocyath reefs from the lower Cambrian Tianheban formation at Wangjiaping, Yichang, Hubei and their diagenesis. Scientia Geologica Sinica 29: 236-245.

Zhang, M.Q., J.S. Hong, S.-J. Choh, and D.-J. Lee. 2017. Thrombolite reefs with archaeocyaths from the Xiannüdong formation (Cambrian series 2), Sichuan, China: Implications for early Paleozoic bioconstruction. Geosciences Journal 21 (5): 655-666.

Zhuravlev, A.Y. 1986. Evolution of archaeocyaths and paleobiogeography of the early Cambrian. Geological Magazine 123 (4): 377-385.

Zhuravlev, A.Y. 1996. Reef ecosytem recovery after the early Cambrian extinction. In Biotic Recovery from Mass Extinction Events, ed. M.B. Hart, vol. 102, 79-96. London, Special Publications: Geological Society.

Zhuravlev, A.Y. 2001. Paleoecology of Cambrian reef ecosystems. In The history and sedimentology of ancient reef systems, ed. G.D. Stanley Jr., 121-157. New York: Kluwer Academic/Plenum Publishers.

Zhuravlev, A.Y., and D.I. Gravestock. 1994. Archaeocyaths from Yorke peninsula, South Australia and archaeocyathan early Cambrian zonation Alcheringa: An Australasian Journal of Palaeontology 18 (1-2): 1-54.

\section{Submit your manuscript to a SpringerOpen ${ }^{\circ}$ journal and benefit from:}

- Convenient online submission

- Rigorous peer review

- Open access: articles freely available online

- High visibility within the field

- Retaining the copyright to your article

Submit your next manuscript at $\boldsymbol{\nabla}$ springeropen.com 